\title{
HUKUM DAN SISTEM HUKUM SEBAGAI PILAR NEGARA
}

\author{
Nur Iftitah Isnantiana \\ Universitas Muhammadiyah Purwokerto, Email : iftitahisnantiana@gmail.com
}

\begin{abstract}
ABSTRAK
Hukum pada dasarnya dibuat untuk menciptakan ketertiban dan kedamaian di dalam masyarakat, oleh karena itu hukum harus dapat ditegakkan dan berjalan sesuai kaidah-kaidah hukum yang berlaku. Manusia yang hidup bermasyarakat dalam suatu negara, mau tidak mau dalam tahap perkembangan kehidupannya akan selalu dihadapkan terhadap sebuah aturan atau hukum yang berlaku. Hukum harus ditegakkan tanpa adanya tebang pilih dalam pelaksanaan hukum oleh para penegak hukum yang didukung oleh kesadaran masyarakat yang tinggi dalam penegakan hukum. Pada dasarnya hukum adalah tatanan dan aturan yang dibuat oleh negara, yang bertujuan untuk mengatur dan mengontrol perilaku masyarakat di suatu negara, sehingga tercipta keadilan dan kedamaian di negara tersebut. Bila penegakkan hukum tidak berjalan dengan baik dapat berakibat terjadinya chaos di tengah masyarakat, dan runtuhlah negara. Sebaliknya jika penegakkan hukum berjalan dengan baik akibatnya keadilan dan kedamaian masyarakat terpelihara dan terjaga sehingga negara bisa tetap berdiri. Oleh karena itu, hukum dapat berperan sebagai pilar negara.

Kata-kata kunci : Hukum; Penegakkan Hukum; Masyarakat; Negara.
\end{abstract}

\section{ABSTRACT}

In based, the law maked for creating rule and peace in the society, so that law must have to standing and walk as rule of law which allowed. Human who living arround society in a nation, want or not in the step growt up of in his living faced a rule ar law allowed. The law must been standed without choices in the law implementation by laws stakeholder and supported by high allowed society in the law standing. In the based, law is a obligation and rule produced by nation, which purposed to ruling and controlling society behaviour, so created fairness and peace in this nation. If the law standing could not doing right it affecting chaos around society, and the nation had broken. Turnback, if the law standing could doing right, affecting society fairness and peace penegakkan have been care and save so the nation still survive. So that, the law could have rule as pillar nations.

Keywords: Law; Law standing; Society; Nation.

\section{PENDAHULUAN}

Hukum tidak dapat dipisahkan dari kehidupan sehari-hari masyarakat dalam suatu negara. Tanpa adanya hukum yang mengatur kehidupan bermasyarakat maka akan menyebabkan ketidakteraturan 
dalam suatu negara. Negara yang tidak teratur akan berimbas kepada terhambatnya pembangunan, karena tidak dapat dipungkiri bahwa Hukum adalah salah satu pilar negara. Hukum adalah aturan yang sifanya memaksa didalamnya pun terdapat sanksi yang tegas apabila aturan-aturan hukum tersebut dilanggar. Ketegasan aturan hukum inilah yang dijadikan salah satu alat untuk mengatur tata kehidupan dalam bernegara sehingga terciptalah negara yang ideal untuk ditinggali dalam suasana nyaman, aman, dan sejahtera. Itulah sebabnya mengapa hukum sebagai salah satu pilar penting dalam suatu negara.

Hukum di suatu negara bertujuan untuk memberikan jaminan ketertiban dan keamanan bagi masyarakat. Ketertiban tersebut akan terjaga apabila masyarakat mentaati hukum yang ada. Hukum tidak cukup diartikan sebagai aturan yang mengikat warganya saja, melainkan harus memiliki aspek keadilan dan asas lain yang berguna melindungi warganya dengan adil, dan menjamin kepastian hukum bagi setiap warga negara, tanpa kecuali. Agar terwujudnya kepastian hukum bagi setiap warga negara, penting bagi seluruh masyarakat untuk mematuhi hukum/ perundang-undangan yang berlaku (Rahardjo, 1986: 25).

Berkaitan dengan peran penting hukum dalam negara untuk menjamin kehidupan bermasyarakat dalam suatu negara, maka penulis bermaksud menguraikannya dalam tulisan ini. Berikut akan disampaikan beberapa keterangan tentang peran hukum sebagai pilar negara. Hukum adalah sistem yang terpenting dalam pelaksanaan atas rangkaian kekuasaan kelembagaan. Menurut Kamus Besar Bahasa Indonesia hukum dapat didefinisikan sebagai berikut: pertama, peraturan atau adat, yang secara resmi dianggap mengikat dan dikukuhkan oleh penguasa, pemerintah atau otoritas. Kedua, undang-undang, peraturan dan sebagainya untuk mengatur kehidupan masyarakat. Ketiga, patokan (kaidah, ketentuan). Keempat, keputusan (pertimbangan) yang ditentukan oleh hakim dalam pengadilan, vonis (Tim Penyusun, 1998: 672). P. Brost mendefinisikan hukum sebagai keseluruhan peraturan bagi kelakuan atau perbuatan manusia di dalam masyarakat. Definisi hukum ini tergolong definisi hukum yang dogmatik-normatif, karena definisi yang menyatakan keseluruhan peraturan bagi perbuatan manusia mengandung arti bahwa dalam pelaksanaannya dapat dipaksakan. Ini adalah ciri dari hukum positif, dan hukum positif bersifat dogmatik-normatif (Suroso, 1992: 27). 
Menurut Immanuel Kant hukum adalah keseluruhan syarat berkehendak bebas dari orang yang satu untuk dapat menyesuaikan diri dengan kehendak bebas dari orang lain, dengan mengikuti peraturan tentang kemerdekaan. Definisi hukum ini tergolong dalam definisi hukum yang non dogmatik karena memandang hukum tidak hanya sebagai peraturan semata tetapi juga memandang hukum sebagai keseluruhan syarat berkehendak bebas dan dapat menyesuaikan diri (Hairi, 2012: 22). Sementara menurut Meyers, hukum adalah semua aturan yang mengandung aturan kesusilaan, ditujukan kepada tingkah laku manusia dalam masyarakat, dan yang menjadi pedoman bagi penguasa-penguasa negara dalam melakukan tugasnya. Definisi hukum ini bersifat non dogmatis dan cenderung bersifat sosiologis. Tidak ada perintah dan larangan, tidak memisahkan antara hukum dan moral (C.S.T. Kansil, 1986: 36). Sedangkan menurut Urecht, hukum adalah himpunan peraturanperaturan yaitu yang mengandung perintah-perintah dan laranganlarangan yang mengurus tata tertib suatu masyarakat dan karena itu harus ditaati oleh masyarakat. Definisi ini tergolong dogmatif normatif karena di dalamnya terkandung makna yang memiliki perintah dan larangan yang harus ditaati oleh masyarakat. Pengertian hukum ini mengandung unsur hukum positif karena disamping ada perintah dan larangan, juga terdapat sanksi. Pengertian hukum ini memisahkan secara tegas antara hukum dan moril serta menganggap hukum sebagai seharusnya dilakukan (das sollen) (Tobing, 2007: 8).

Weber berpandangan bahwa hukum adalah suatu tatanan yang bersifat memaksa karena tegaknya tatanan hukum itu (berbeda dari tatanan-tatanan dan norma-norma sosial lain yang bukan hukum) ditopang sepenuhnya oleh kekuatan pemaksa yang dimiliki oleh negara. Weber membedakan berbagai sistem hukum atas dasar rasionalitas yang substantif dan formal. Weber mengatakan bahwa memiliki rasionalitas yang substantif tatkala substansi hukum itu memang terdiri atas aturan-aturan umum in abstracto yang siap dideduksikan guna menghukumi berbagai kasus-kasus konkret. Sebaliknya, hukum dikatakan tidak memiliki rasionalitas yang substantif jika setiap perkara diselesaikan atas dasar kebijaksanaan-kebijaksanaan politik atau etika yang unik dalam tatanannya. Bahkan mungkin juga diselesaikan secara emosional yang sama sekali tidak bisa merujuk ke aturan-aturan umum yang secara 
objektif ada. Sebaliknya, hukum bisa dikatakan memiliki rasionalitas yang formal (irasional) jika hukum itu hanya diperoleh melalui ilham-ilham atau lewat bisikan-bisikan wangsit yang konon diterima oleh para pemuka karismatis sehingga kebenaran dan kelaikannya tidak bisa diuji secara objektif (Wignjosoebroto, 2008: 36-37).

Paradigma yang memandang hukum sebagai suatu sistem telah mendominasi pemikiran sebagian terbesar kalangan hukum, baik para teoritisi maupun kalangan praktisinya sejak lahirnya negara modern pada abad ke-17 hingga saat ini, yaitu paradigma yang menganggap hukum sebagai suatu keteraturan (order) (Fadjar, 2013: 1). Hukum sebagai suatu sistem, menurut L. Friedman memiliki beberapa komponen yaitu meliputi: pertama, struktur, diibaratkan sebagai mesin yang di dalamnya ada institusi-institusi pembuat dan penegakan hukum seperti DPR, Eksekutif, Legislatif, kepolisian, kejaksaan dan pengadilan. Terkait dengan ini, maka perlu dilakukan seleksi yang objektif dan transparan terhadap aparat penegak hukum. Kedua, substansi, merupakan apa yang dikerjakan dan dihasilkan oleh mesin itu, yang berupa putusan dan ketetapan, aturan baru yang disusun, substansi juga mencakup aturan yang hidup dan bukan hanya aturan yang ada dalam kitab undang-undang. Selain itu, substansi suatu peraturan perundang-undangan juga dipengaruhi sejauh mana peran serta atau partisipasi masyarakat dalam merumuskan berbagai kepentingannya untuk dapat diatur lebih lanjut dalam suatu produk peraturan perundang-undangan. Adanya keterlibatan masyarakat dalam pembentukan suatu undang-undang akan memberikan dampak terhadap efektivitas pemberlakuan dari undang-undang tersebut. Ketiga, kultur hukum, menyangkut apa saja atau siapa saja yang memutuskan untuk menghidupkan dan mematikan mesin itu, serta memutuskan bagaimana mesin itu digunakan, yang mempengaruhi suasana pikiran sosial dan kekuatan sosial yang menentukan bagaimana hukum digunakan, dihindari atau disalahgunakan. (Soekanto, 2003: 67).

Ketiga komponen di atas harus berjalan beriringan yaitu struktur harus kuat, kredibel, akuntabel, dan capable. Substansi harus selaras dengan rasa keadilan masyarakat sedang budaya hukumnya harus mendukung tegaknya hukum jika salah satunya timpang, misal struktur aparat (law unforercement officer) tidak akuntable, credible dan capable mustahil hukum dapat ditegakkan. Agar hukum dapat efektif sebagai sarana kontrol 
terhadap masyarakat maka sistem hukum yang dimaksud perlu diperbaiki yaitu pada ketiga komponen sistem hukum di atas. Dengan demikian, manusia yang hidup dalam masyarakat mau tidak mau dalam tahap perkembangan kehidupannya akan selalu dihadapkan terhadap sebuah aturan atau hukum yang berlaku. Norma yang ada dalam masyarakat mencakup norma agama, hukum, kesopanan, dan kesusilaan. Hukum yang ada dalam masyarakat yaitu hukum yang digunakan untuk mengatur terhadap kasus-kasus yang rasionalitas, yaitu bersifat empiris bukan spekulatif. Jika hukum ditegakkan dengan keadilan maka hukum akan dijunjung tinggi di masyarakat.

\section{PEMBAHASAN}

Negara adalah sekumpulan orang yang dalam mencapai tujuan bersama, mengadakan kerjasama, dan pembagian kerja di bawah satu pemimpin yang memiliki kemampuan untuk memaksakan kehendaknya. Definisi Negara dalam Kamus Besar Bahasa Indonesia organisasi dalam suatu wilayah yang mempunyai kekuasaan tertinggi yang sah dan ditaati oleh rakyat. Atau kelompok sosial yang menduduki wilayah atau daerah tertentu yang diorganisasi di bawah lembaga politik dan pemerintah yang efektif, mempunyai kesatuan politik, berdaulat sehingga berhak menentukan tujuan nasionalnya. Menurut Plato dalam Soehino (1980: 17), negara adalah suatu tubuh yang senantiasa maju, berevolusi dan terdiri dari orang-orang (individu-individu) yang timbul atau ada karena masing-masing dari orang itu secara sendiri-sendiri tidak mampu memenuhi kebutuhan dan keinginannya yang beraneka ragam, yang menyebabkan mereka harus bekerja sama untuk memenuhi kepentingan mereka bersama.

Suatu Negara dapat saja lahir dan hidup tetapi itu belum berarti bahwa Negara tersebut mempunyai kedaulatan, kedaulatan ialah kekusaan tertinggi yang dimiliki oleh suatu Negara untuk secara bebas melakukan berbagai kegiatan sesuai kepentingannya, asal kegiatanya tersebut tidak bertentangan dengan hukum internasional. Sesuai konsep hukum internasional kedaulatan memiliki tiga aspek utama yaitu: pertama, aspek ekstern kedaulatan adalah hak bagi setiap negara untuk secara bebas menentukan hubungannya dengan berbagai negara atau kelompokkelompok lain tanpa tekanan atau pengawasan dari negara lain. Kedua, 
aspek intern kedaulatan ialah hak atau wewenang eksklusif suatu negara untuk menentukan bentuk lembaga-lembaganya, cara kerja lembagalembaganya tersebut dan hak untuk membuat undang-undang yang diinginkannya serta tindakan-tindakan untuk mematuhi. Ketiga, aspek territorial kedaulatan berarti kekuasaan penuh dan eksklusif yang dimiliki oleh Negara atas individu-individu dan benda-benda yang terdapat di wilayah tersebut (Mauna, 2005: 24).

Negara merupakan subjek hukum yang terpenting dibanding dengan subjek-subjek hukum internasional lainnya. Pasal 1 konvensi Montevideo 27 Desember 1933 mengenai hak dan kewajiban negara menyebutkan bahwa negara sebagai subjek dalam hukum internasional harus memiliki empat unsur yaitu penduduk yang tetap, wilayah tertentu, pemerintahan yang berdaulat, dan kapasitas untuk berhubungan dengan negara lain (Thontowi, 2006: 105). Upaya masyarakat Internasional mempersoalkan hak-hak dan kewajiban-kewajiban Negara-negara telah dimulai sejak abad ke-17 dengan landasan teori kontrak sosial. Pada tahun 1916 American Institute of International law (AIIL) mengadakan seminar dan menghasilkan Declaration of the Right and Duties of Nations yang diusul dengan sebuah kajian yang berjudul Fundamental Right and Duties of American Republics dan sampai dirampungkannya konvensi Montevideo tahun 1933. Hasil konvensi Montevideo ini kemudian menjadi rancangan deklarasi tentang hak dan kewajiban Negara-negara yang disusun oleh Komisi Hukum Internasional PBB pada tahun 1949, Namun komisi tersebut tidak pernah berhasil menghasilkan usulan yang memuaskan negara-negara (Adolf, 1996: 37).

Deklarasi prinsip-prinsip mengenai hak dan kewajiban Negara yang terkandung dalam rancangan tersebut adalah sebagai berikut: pertama, hak-hak negara yang meliputi hak atas kemerdekaan, hak melaksanakan yuridis terhadap wilayah, orang dan benda yang berada di dalam wilayahnya, hak mendapatkan kedudukan hukum yang sama dengan negara-negara lain, dan hak menjalankan pertahanan diri sendiri atau kolektif. Kedua, kewajiban-kewajiban Negara yang terdiri dari kewajiban negara tidak melakukan intervensi terhadap masalah-masalah yang terjadi di negara lain, kewajiban untuk tidak menggerakkan pergolakan sipil di negara lain, kewajiban untuk tidak menggerakkan semua orang yang berada di wilayahnya dengan memperhatikan hak-hak asasi manusia, 
kewajiban untuk menjaga wilayahnya agar tidak membahayakan perdamaian dan keamanan internasional, dan kewajiban untuk mengadakan hubungan dengan negara-negara lain sesuai dengan hukum internasional.

Hukum dapat tercipta bila masyarakat sadar akan hukum tanpa membuat kerugian pada orang lain. Penegakan hukum di Indonesia tidak terlepas dari peran para aparat penegak hukum. Menurut Pasal 1 Bab 1 Kitab Undang-Undang Hukum Acara Pidana (KUHAP), yang dimaksud aparat penegak hukum oleh undang-undang tersebut adalah: pertama, penyelidik adalah pejabat polisi Republik Indonesia atau pejabat Pegawai Negeri Sipil tertentu yang diberikan wewenang khusus oleh undangundang untuk melakukan penyelidikan. Kedua, jaksa adalah pejabat yang diberi wewenang oleh undang-undang untuk bertindak sebagai penuntut umum serta melaksanakan putusan pengadilan yang telah memperoleh hukum tetap. Ketiga, penuntut umum adalah jaksa yang diberi wewenang oleh undang-undang ini untuk melakukan penuntutan dan melaksanakan ketetapan hakim. Keempat, hakim adalah pejabat peradilan yang diberi wewenang oleh undang-undang untuk mengadili. Kelima, penasehat hukum adalah seseorang yang memenuhi syarat yang ditentukan oleh undang-undang untuk memberikan bantuan hukum (Soekanto, 2005: 64).

Ruang lingkup dari istilah "penegak hukum" adalah luas sekali, karena mencakup mereka yang secara langsung dan secara tidak langsung berkecimpung di bidang penegakan hukum mencakup yang bertugas di bidang-bidang Kehakiman, Kejaksaan, Kepolisian, Kepengacaraan, dan Pemasyarakatan (Soerjono Soekanto, 2005: 64). Secara sosiologis, setiap penegak hukum mempunyai kcdudukan (status) dan peranan (role). Kedudukan (sosial) merupakan posisi tertentu di dalam struktur kemasyarakatan, yang mungkin tinggi, sedang-sedang saja atau rendah. Kedudukan tersebut sebenarnya merupakan suatu wadah yang isinya adalah hak-hak dan kewajiban- kewajiban tertentu yang merupakan peranan atau role. Oleh karena itu, seseorang yang mempunyai kedudukan tertentu, lazimnya dinamakan pemegang peranan (role occupant) Suatu hak sebenarnya merupakan wewenang untuk berbuat atau tidak berbuat, sedangkan kewajiban adalah beban atau tugas suatu peranan tertentu, dapat dijabarkan ke dalam unsur-unsurnya berikut, peranan yang ideal (ideal role), peranan yang seharusnya (expected role), peranan yang dianggap 
oleh diri sendiri (perceived, role), peranan yang sebenarnya dilakukan/actual role (Soekanto, 2005: 64).

Seorang penegak hukum, sebagaimana haInya dengan warga-warga masyarakat lainnya, lazimnya mempunyai beberapa kedudukan dan peranan sekaligus. Dengan demikian tidaklah mustahil, bahwa antara pelbagai kedudukan dan peranan timbul konflik (status conflict dan conflict of roles). Kalau di dalam kenyataannya terjadi suatu kesenjangan antara peranan yang seharusnya dengan peranan yang sebenarnya dilakukan atau peranan aktual, maka terjadi suatu kesenjangan peranan (role-distance). Terjadinya kesenjangan peran dan menimbuklan konflik pribadi pada aparat penegak hukum dapat mengakibatkan tidak terwujudnya penegakan hukum sebagaimana yang seharusnya (Soerjono Soekanto, 2005: 68). Hukum pada dasarnya dibuat untuk menciptakan ketertiban dan kedamaian di dalam masyarakat, oleh karena itu harus hukum harus ditegakkan. Penegakan hukum adalah proses dilaksanakannya upaya untuk tegaknya atau berfungsinya norma-norma hukum secara nyata sebagai pedoman prilaku dalam hubungan-hubungan hukum dalam kehidupan bermasyarakat dan bernegara. Pada dasarnya manusia adalah makhluk yang bertindak merespons dan beraksi, sehingga terciptalah berbagai kegiatan dalam kehidupan baik yang bersifat positif maupun negatif. Manakala tidak ada sistem sosial (aturan sosial) di masyarakat yang menertibkan dan mengorganisir tindakan tersebut, maka keberadaan peraturan perundangan atau hukumlah sebagai alat kontrolnya (hukum sebagai kontrol sosial dan sistem sosial) (Utsman, 2013 : 185).

Penegakan hukum dapat diartikan sebagai usaha melaksanakan hukum sebagaimana mestinya, mengawasi pelaksanaanya agar tidak terjadi pelanggaran, dan jika terjadi pelanggaran memulihkan hukum yang dilanggar itu supaya ditegakan kembali. Penegakan hukum dilakukan dengan penindakan hukum menurut urutan sebagai berikut: pertama, teguran peringatan supaya menghentikan pelanggaran dan jangan berbuat lagi (percobaan). Kedua, pembebanan kewajiban tertentu (ganti kerugian, denda). Ketiga, penyisihan dan pengucilan (pencabutan hak-hak tertentu). Keempat, pengenaan sanksi badan dalam hal ini pidana penjara atau pidana mati (Muhammad, 2006: 115). Hukum harus dilaksanakan dan ditegakkan. Setiap orang menginginkan dapat ditetapkannya hukum terhadap peristiwa konkrit yang terjadi. Bagaimana hukumnya, itulah yang 
harus diberlakukan pada setiap peristiwa yang terjadi. Pelaksanaan hukum dapat terjadi karena pelanggaran hukum, yaitu dengan menegakan hukum tersebut dengan bantuan alat-alat perlengkapan Negara. Dalam menegakan hukum kemanfaatan dan keadilan (Soedikno, 1986: 180). Menegakan hukum di suatu negara tidak semudah membalikan telapak tangan, karena banyak faktor-faktor penghambat. Menurut Soerjono Soekanto(2005: 77-79) yang menjadi faktor-faktor penegakan hukum di Indonesia, adalah :

1. Undang-Undang

Semakin baik suatu peraturan hukum akan semakin baik memungkinkan penegakannya. Sebaliknya, semakin tidak baik suatu peraturan hukum akan semakin sukarlah menegakannya. Secara umum peraturan yang baik adalah peraturan hukum yang berlaku secara yuridis, sosiologis, dan filosofis. Secara Yuridis, setiap peraturan hukum yang berlaku haruslah bersumber pada peraturan yang lebih tinggi tingkatannya. Ini berarti bahwa setiap peraturan hukum yang berlaku tidak boleh bertentangan dengan peraturan hukum yang lebih tinggi derajatnya. Misalnya, Undang-Undang di Indonesia dibentuk oleh Presiden dengan persetujuan Dewan Perwakilan Rakyat. Secara Sosiologis, bilamana peraturan hukum tersebut diakui atau diterima oleh masyarakat kepada siapa peraturan hukum itu ditujukan/diberlakukan menurut "Anerkennungstheorie", "The Recogniton Theory". Teori ini bertolak belakang dengan "Machttheorie", Power Theory". Yang menyatakan, bahwa peraturan hukum mempunyai kelakuan sosiologis apabila dipaksakan berlakunya oleh penguasa, diterima ataupun tidak oleh warga masyarakat. Secara Filosofis, apabila peraturan hukum tersebut sesuai dengan cita-cita hukum (rechsidde) sebagai nilai positif yang tertinggi dalam negara Inodonesia, cita-cita hukum sebagai nilai positif yang tertinggi adalah masyarakat yang adil dan makmur berdasarkan Pancasila dan UUD 1945.

2. Faktor Penegak Hukum

Secara sosiologis setiap penegak hukum tersebut mempunyai kedudukan (status) atau peranan (role). Kedudukan sosial merupakan posisi tertentu dalam struktur masyarakat yang isisnya adalah hak dan kewajiban. Penegakan hukum dalam mengambil keputusan diperlukan 
penilaian pribadi yang memegang peranan karena: pertama, tidak ada perundingan Undang-Undang yang sedemikian lengkap, sehingga dapat mengatur prilaku manusia. Kedua, adanya hambatan untuk menyelesaikan perundang-undangan sesuai dengan perkembangan masyarakat sehingga menimbulkan ketidakpastian. Ketiga, kurangnya biaya untuk menerapkan Perundang-undangan. Keempat, adanya kasus-kasus individu yang memerlukan penanganan khusus.

3. Faktor Sarana atau Fasilitas

Sarana atau fasilitas antara lain mencangkup tenaga manusia yang berpendidikan dan terampil, organisasi yang baik, peralatan yang memadai, keuangan yang cukup dan seterusnya. Apabila hal-hal itu tidak terpenuhi maka sukar bagi penegak hukum akan mencapai tujuannya. Misalnya, untuk membuktikan apakah suatu tanda tangan palsu atau tidak, kepolisian di daerah tidak dapat mengetahui secara pasti, karena tidak mempunyai alat untuk memeriksanya, sehingga terpaksa dikirim ke tempat yang bisa menyelesaikannya. Tanpa sarana atau fasilitas yang memadai, penegak hukum tidak akan dapat berjalan lancar dan penegak hukum tidak bisa berjalan dengan sempurna.

4. Faktor Masyarakat

Semakin tinggi kesadaran hukum masyarakat maka akan semakin memungkinkan penegakan hukum berjalan dengan sempurna. Tetapi semakin rendah tingkat kesadaran yang dimiliki oleh masyarakat maka akan semakin sukar untuk melaksanakan penegakan hukum yang baik. Kesadaran hukum merupakan suatu pandangan yang hidup dalam masyarakat tentang apa yang dimaksud dengan hukum. Pandangan itu berkembang dan dipengaruhi oleh berbagai faktor, seperti agama, ekonomi, politik, dan sebagainya. Pandangan itu selalu berubah, maka diperlukan upaya dari kesadaran hukum, yaitu: pengetahuan hukum, pemahaman hukum, sikap terhadap norma-norma, dan perilaku hukum.

5. Faktor Kebudayaan

Kebudayaan pada dasarnya mencangkup nilai-nilai yang mendasari hukum yang berlaku, nilai-nilai mana yang merupakan konsepsi-konsepsi abstrak mengenai apa yang dianggap baik dan apa 
yang dianggap tidak baik. Maka kebudayaan Indonesia merupakan dasar atau hal yang mendasari hukum adat yang berlaku, disamping itu berlaku pula hukum tertulis (perundang-undangan), yang dibentuk oleh golongan tertentu dalam masyarakat yang mempunyai kekuasaan dan wewenang untuk itu. Hukum perundang-undangan tersebut harus dapat mencerminkan nilai-nilai yang menjadi dasar dari hukum adat, agar hukum perundang-undangan tersebut dapat berlaku secara aktif.

Kelima faktor di atas, saling berkaitan erat, karena merupakan esensi dari penegakan hukum, juga merupakan tolok ukur daripada efektivitas penegakan hukum. Pada hakekatnya tujuan penegakan hukum adalah untuk mewujudkan apa yang hendak dicapai oleh hukum. Tujuan hukum adalah mencapai keseimbangan agar hubungan yang ditimbulkan oleh kepentingan masyarakat tidak terjadi kekacauan. Secara umum tujuan hukum adalah mencapai tiga hal yakni, kepastian hukum, keadilan dan daya guna (Teguh Prasetyo, 2013: 54).

Penegakan hukum seharusnya akuntabel, tidak memihak dan tidak mudah diintervensi sehingga hasilnya dapat dipertanggungjwabkan di hadapan publik, karena penegakan hukum tak dapat berdiri sendiri tanpa adanya sistem hukum itu sendiri. Tujuan akhir hukum adalah keadilan, oleh karena itu segala usaha yang terkait dengan hukum mutlak harus diarahkan untuk menemukan sebuah sistem hukum yang paling cocok dan sesuai dengan prinsip keadilan. Hukum harus terjalin erat dengan keadilan, hukum adalah undang-undang yang adil. Bila suatu hukum konkrit, yakni undang-undang bertentangan dengan pinsip-prinsip keadilan, maka hukum itu tidak bersifat normatif lagi dan tidak dapat dikatakan sebagai hukum lagi. Undang-undang hanya menjadi hukum bila memenuhi prinsip-prinsip keadilan. Dengan kata lain, adil merupakan unsur konstitutif segala pengertian tentang hukum (Theo, 1995: 70).

Penegakan hukum yang akuntabel (bertanggung jawab) dapat diartikan sebagai suatu upaya pelaksanaan penegakan hukum yang dapat dipertanggungjawabkan kepada publik, bangsa dan negara yang berkaitan terhadap adanya kepastian hukum dalam sistem hukum yang berlaku, juga berkaitan dengan kemanfaatan hukum dan keadilan bagi masyarakat. Proses penegakan hukum memang tidak dapat dipisahkan dengan sistem hukum itu sendiri. Sedang sistem hukum dapat diartikan merupakan bagian-bagian proses/tahapan yang saling bergantung yang harus 
dijalankan serta dipatuhi oleh penegak hukum dan masyarakat yang menuju pada tegaknya kepastian hukum (Jannatul, 1979: 29).

Hukum merupakan salah satu bidang yang keberadaannya sangat essensial sifatnya untuk menjamin kehidupan bermasyarakat dan bernegara, apalagi negara Indonesia adalah negara hukum, yang berarti bahwa setiap perbuatan aparat negara harus berdasar hukum, serta setiap warga harus mentaati hukum. Dengan perkembangan dunia yang semakin kompleks dewasa ini, maka tidak jarang pula menimbulkan berbagai permasalahan serius yang perlu mendapatkan perhatian sedini mungkin. Permasalahan yang timbul itu, baik berupa pelanggaran terhadap norma-norma yang ada dalam kehidupan bermasyarakat ataupun aturan-aturan yang bertendensi untuk menciptakan suatu fenomena yang bertentangan dengan kaidah moral dan kaidah susila serta aturan-aturan hukum. Pelanggaran yang terjadi merupakan realitas dari keberadaan manusia yang tidak bisa menerima aturan-aturan itu secara keseluruhan. Kalau hal semacam itu terus dibiarkan berlarut-larut dan kurang mendapat perhatian, maka akan menimbulkan keresahan dalam masyarakat sehingga dapat mengganggu ketertiban umum (Wignjosoebroto, 2008: 390).

Dewasa ini memang para pelaku kejahatan atau pelanggaran terhadap norma yang ada semakin marak terjadi. Entah disengaja atau bukan yang namanya tindakan yang bertentangan dengan hukum maka akan mendapatkan sanksi yang tegas. Setiap perilaku dalam mengabaikan atau melawan terhadap norma dalam masyarakat akan dihadapkan pada hukum yang berlaku sesuai dengan undang-undang yang telah dibuat dan disepakati bersama. Dalam hal aparat penegak hukumnya, pada badan-badan penegak hukum terjadi monopoli atas kekerasan yang memang dibenarkan oleh negara. Pada umumnya aparat penegak hukum dengan segala institusinya adalah menjaga ketertiban dan kedaulatan negara. Persenyawaan ini semakin menggelinding ketika negara sangat tergantung kepada keahlian dan ketaatan para penegak hukum terhadap tugas yang diembannya. Dan kenyataan yang demikianlah maka kontrol masyarakat tidak berdaya (berada pada posisi fatalisme "sub-human") Masyarakat hanya akan taat dan tunduk terhadap perlakuan hukum yang ada, biar bagaimanapun unsur kekuasaan akan berpengaruh terhadap dominasi dalam struktur hukum (Utsman, 2013 : 252). Hukum semestinya ditegakkan dan dijalankan sebagaimana mestinya, namun pada 
kenyataannya dalam proses penegakan hukum tidak demikian adanya. Terkadang para penegak hukum tidak mengambil keputusan yang memenuhi unsur keadilan sehingga penegakan hukum condong kepada kepentingan satu pihak dan merugikan pihak lainnya. Fungsi hukum seolah-olah menjadi bergeser, hukum dihadapkan pada berbagai arena kepentingan. Penegakan hukum seyogyanya dapat berjalan sesuai dengan tujuan hukum, sehingga hukum akan berjalan apa adanya tanpa adanya tekanan dari pihak mana saja (Utsman, 2013 : 266).

Pelaksanaan hukum dapat terjadi karena pelanggaran hukum, yaitu dengan menegakan hukum tersebut dengan bantuan alat-alat perlengkapan negara dalam rangka menegakan hukum yang berazas kemanfaatan dan keadilan (Sudikno, 1986: 130). Hukum yang berjalan dalam masyarakat merupakan sebuah perwujudan dari pengendalian sosial, siapa yang melakukan pelanggararan hukum, maka akan berada pada pusaran/lingkaran peraturan hukum. Hukum berlaku bagi semua kalangan, tidak mengenal stratifikasi sosial dalam penegakan hukum, tetapi realita yang terjadi berbanding terbalik dari prinsip hukum, hukum dijadikan alat bagi mereka yang mempunyai kepentingan. menertibkan dan mengorganisir maka keberadaan peraturan perundangan atau hukumlah sebagai alat kontrol sosial dan sistem sosial (Utsman, 2013 : 185).

Hukum yang diterapkan dalam masyarakat di sutu negara akan membawa pengaruh bagi masyarakat sebuah negara. Apalagi, partisipasi civil society dalam pembentukan undang-undang merupakan suatu keniscayaan dengan tujuan mengimbangi dan mengontrol kebijakan penyelenggara Negara (Setiawan, 2018: 159). Dampak diberlakukannya hukum di negara tersebut akan berpengaruh terhadap individu atau kelompok dalam masyarakat yang sedang bermasalah dengan hukum, keluarga, kelompok, atau organisasi kemasyarakatan, masyarakat dalam arti luas, dan media massa pun turut berperan andil dalam sebuah kabar berita pada hukum yang berlaku di masyarakat (Soerjono Soekanto, 2005: 77-79). Dalam proses penegakan hukum, pengadilan yang memutuskan terhadap sebuah perkara. Terdapat hubungan sosial yang terjadi dalam proses penegakan hukum dan putusan hukum sehingga akan menimbulkan dampak secara sosial. Hukum tidak memandang kelas-kelas sosial, kesadaran masyarakat dalam berhukum yang akan menentukan terhadap jalannya penegakan hukum tersebut. Hal yang menjadi acuan 
dalam realitas objektif masyarakat yang bersumber terciptanya aturan atau sanksi yang berlaku dari Negara atau pemerintah adalah pada tataran hukum. Hukum bersifat tegas dan memaksa manakala bertujuan agar dalam tatanan masyarakat tercipta ketertiban dan kedamaian, maka hukum yang ada harus akuntabel (Rahardjo, 1986: 42). Kondisi penegakan hukum yang demikian dapat mewujudkan peran hukum sebagai pilar negara.

Peran hukum sebagai pilar negara dapat terealisir secara maksimal apabila didukung oleh sistem penegakan hukum yang akuntabel. Dalam rangka membentuk dan membangun sistem penegakan hukum yang akuntabel perlu melibatkan seluruh stakeholder dan yang terpenting adalah dukungan pemerintahan yang bersih (clean government). Dukungan pemerintahan yang bersih dalam membangun penegakan hukum yang akuntabel harus total, karena penegakan hukum adalah bagian dari sistem hukum pemerintahan. Pemerintah harus berada di garda terdepan dalam penegakan hukum untuk memberikan harapan kepada masyarakat atas kepastian hukum. Penegakan rule of law menurut W. Friedmann, meliputi: pertama, penegakan hukum yang sesuai dengan ukuran-ukuran tentang hukum yang baik atau hukum yang buruk. Kedua, kepatuhan dari warga-warga masyarakat terhadap kaidah-kaidah hukum yang dibuat serta diterapkan oleh badan-badan legislatif, eksekutif dan yudikatif. Ketiga, kaidah-kaidah hukum harus selaras dengan hak-hak asasi manusia. Keempat, negara mempunyai kewajiban untuk menciptakan kondisikondisi sosial yang memungkinkan terwujudnya aspirasi-aspirasi manusia dan penghargaan yang wajar terhadap martabat manusia. Kelima, adanya badan yudikatif yang bebas dan merdeka yang akan dapat memeriksa dan memperbaiki setiap tindakan yang sewenang-wenang dari badan eksekutif dan legislatif (Soekanto, 2003: 83).

Penegakan hukum bukanlah suatu hal yang berdiri sendiri, melainkan ia saling berkait dengan masalah-masalah sosial masyarakat lainnya. Artinya hukum bukan hanya sebagai sistem nilai, tetapi juga hukum sebagai sub sistem dari sistem sosial yang lebih besar, yaitu masyarakat dimana hukum diberlakukan. Kaidah-kaidah tersebut kemudian menjadi pedoman atau patokan bagi perilaku atau sikap tindak yang dianggap pantas, atau yang seharusnya. Perilaku atau sikap tindak tersebut bertujuan untuk menciptakan, memelihara, dan mempertahankan 
kedamaian (Wignjosoebroto, 2002: 62). Kesadaran hukum yang merupakan jembatan penghubung antara hukum dengan perilaku masyarakat, terkait erat dengan budaya hukum masyarakatnya dengan kata lain dapat dijelaskan bahwa tingkat kesadaran hukum masyarakat tinggi atau rendah dapat dilihat pada budaya hukumnya, jika budaya hukumnya cenderung positif, proaktif terhadaap cita hukum tentu masyarakatnya memilki kesadaran hukum yang tinggi. Dalam hal ini fungsi hukum mengalami perluasan yang mulanya sebagai kontrol sosial dan pertahanan pola sosial bergeser ke arah perubahan tingkah laku yang dikehendaki hukum. Jika demikian dapat digeneralisasikan bahwa tingkah laku masyarakat Negara dapat dilihat pada hukumnya (Rahardjo, 1986: 58).

Hukum sebagai sistem nilai sekaligus sebagai sub-sistem dari sistem sosial sebenarnya menjabarkan bahwa hukum merupakan das sein dan das solen, di sisi lainnya antara das sein dan das sollen tidak mudah dipertemukan bahkan seringkali bertolak belakang dengan perilaku hukum masyarakat yang seharusnya. Sulitnya penyelarasan hukum sebagai "sein" dan hukum sebagai "solen" tidak terlepas dari faktor-faktor non yuridis yang hidup dan berkembang yang salah satunya dalah kultur hukum. Budaya sebagai produk masyarakat amat beragam dan berbeda tidak hanya masyarakat satu dengan lainnya pun berbeda sehingga akibat tingkatan-tingkatan sosial dalam lingkungan misalnya budaya hukum seorang pedagang dengan guru, sopir dengan pegawai dan sebagainya (Wignjosoebroto, 2002: 62). Hukum merupakan suatu alat untuk memelihara ketertiban dalam masyarakat. Mengingat fungsinya sifat hukum, pada dasarnya adalah konservatif artinya, hukum bersifat memelihara dan mempertahankan yang telah tercapai. Fungsi demikian diperlukan dalam setiap masyarakat, termasuk masyarakat yang sedang membangun, karena di sini pun ada hasil-hasil yang harus dipelihara, dilindungi dan diamankan (Kusumaatmadja, 1986: 9).

\section{PENUTUP}

Hukum di suatu negara diperankan sebagaimana mestinya sesuai kaidah-kaidan hukum (das sein) di mana para penegak hukum dalam upaya penegakan hukum lebih cermat dalam memahami hukum secara luas dan mendalam demi mencapai keadilan, dan didukung oleh masyarakat yang memiliki kesadaran hukum. Maka hukum benar-benar 
dapat berperan sebagai pilar negara. Hukum merupakan wujud dari tata peraturan yang mengatur suatu negara. Di sini hukum akan berfungsi sebagai instrumen untuk menjaga keserasian dan kenyamanan hubungan dalam bermasyarakat. Objektivitas dalam penegakan hukum hanya dapat dilakukan oleh para aparatur yang profesional dan memiliki integritas moral yang tinggi. Hukum ditegakkan, barang siapa yang melanggar maka sanksi yang didapatkan tegas dan memaksa. Hukum diterapkan tanpa pandang bulu, setiap masyarakat baik yang berasal dari golongan kelas menengah kebawah dan golongan kelas atas harus mendapatkan perlakuan yang sama di mata hukum. Hukum dijunjung tinggi, sehingga nilai-nilai hukum akan mendapat tempat bagi masyarakat, dan negara bisa tetap bertahan dan berkembang bersama keadilan dan kedamaian yang melingkupinya.

\section{DAFTAR REFERENSI}

Abdulkadir Muhammad. 2006. Etika Profesi Hukum. Bandung: PT. Citra Aditya Bakti.

Adolf, Huala. 1991. Aspek-aspek Negara dalam Hukum Internasional. Jakarta: Rajawali.

C.S.T. Kansil. 1986. Penganatar Ilmu Hukum dan Tata Hukum Indonesia. Jakarta: Balai Pustaka.

Fadjar, Mukthie. 2013. Teori-Teori Hukum Kontemporer. Malang : Setara Press. Hairi, Wawan Muhwan. 2012. Pengantar Ilmu Hukum. Jakarta: Pustaka Setia. Jannatul, MS. 1979. Hukum dan Masyarakat: Pentingnya Hukum Bagi Masyarakat. Jakarta: Aksara Baru.

Kelsen, Hans, 2007. Teori Hukum Murni: Dasar-dasar Ilmu Hukum Normatif. Bandung: Penerbit Nusamedia.

Mauna, Boer. 2005. Hukum Internasional (Pengertian, Peranan dan Fungsi dalam Era Dinamika Globalisasi). Edisi ke-2. Bandung: Alumni.

Miriam Budiardjo. 2012. Dasar-Dasar Ilmu Politik. Jakarta: Gramedia Pustaka Utama.

M.L. Tobing. 2007. Sekitar Pengantar Ilmu Hukum. Jakarta: Erlangga.

Mokhtar Kusumaatmadja. 1986. Pembinaan Hukum dalam rangka Pembangunan Nasional. Bandung: Binacipta,

Rahardjo, Satjipto. 1986. Ilmu Hukum. Bandung: Alumni.

Soehino. 1980. Ilmu Negara. Yogyakarta: Liberty.

Soerjono Soekanto. 2005. Pokok-Pokok Sosiologi Hukum. Jakarta: PT. Raja 
Grafindo Persada,

Setiawan, Adam. "Partisipasi Civil Society dalam Pembentukan Undang-Undang." JURNAL HUKUM EKONOMI SYARIAH 1.2 (2019): 159-176.

Sudikno Mertokusumo. 1986. Hukum Mengubah. Yogyakarta: Liberty.

Suroso. 1992. Pengantar Ilmu Hukum. Jakarta: Sinar Grafika.

Teguh Prasetyo. 2013. Hukum dan Sistem Hukum Berdasarkan Pancasila. Yogyakarta: Media Perkasa.

Theo Hujibers, 1995. Filsafat Hukum dalam Lintasan Sejarah. Yogyakarta: Kanisius.

Thontowi, Jawahir dan Pranoto Iskandar. 2006. Hukum Internasional Kontemporer, Refika Aditama, Bandung.

Utsman, Sabian. 2013. Dasar-Dasar Sosiologi Hukum. Yogyakarta : Pustaka Pelajar.

Wignjosoebroto, Soetandyo. 2002. Hukum: Paradigma, Metode dan Dinamika Masalahnya. Jakarta: Elsam.

Wignjosoebroto, Soetandyo. 2008. Hukum dalam Masyarakat. Malang: Bayumedia Publishing. 